\title{
Histone Deacetylase 2
}

National Cancer Institute

\section{Source}

National Cancer Institute. Histone Deacetylase 2. NCI Thesaurus. Code C18294.

Histone deacetylase 2 ( $488 \mathrm{aa}, \sim 55 \mathrm{kDa}$ ) is encoded by the human HDAC2 gene. This protein plays a role in histone deacetylation, chromatin remodeling and embryonic structure development. 